\title{
民間非営利組織を中心とした住宅地の開発マネジメント手法に関する考察 一米国ニューメキシコ州ティエラコンテンタ開発のケーススタディを通して - METHODS OF DEVELOPMENT MANAGEMENT FOR RESIDENTIAL AREA
BY NON-PROFIT ORGANIZATION
}

A case study of Tierra Contenta development in New Mexico, United States of America

\author{
森傑* \\ Suguru MORI
}

\begin{abstract}
This study aims to consider possibilities of development management for residential area by non-profit organization through theoretical analysis and a case study about concrete ideas and systems of a pioneer project in the United States. Tierra Contenta Corporation, which is the non-profit organization in the United States, has been developing Tierra Contenta residential area in Santa Fe, New Mexico. This development aims to create mixed-income community in the situation of gentrification and urban sprawl. The important points of an argument to consider methods of development management by public-private partnership in Japan are following: One is that the roundtable consists of pluralistic individuals should be problem-based. It is indispensable for this roundtable to have privatization and constitution as the non-stock corporation. And the other is the project-based non-profit organization. Japan doesn't have a grounding in non-stock corporations culturally and institutionally, so that it means a kind of strategy to train NPOs fundamentally in Japan.
\end{abstract}

Keywords : affordability, non-profit organization, management, project-based, public-private partnership アフォーダビリティ, NPO, マネジメント，プロジェクトベース，PPP

\section{1. 目的と背景}

本研究は、住宅地マネジメントに対して実践力のある民間非営利 組織（以下、NPO）の活動支援に関する制度およびシステムが十 分には確立されていない日本において、近い将来確実に求められる Public-Private Partnership によるアフォーダブル・コミュニティ の質の高い整備を実現すべく、NPO 先進国である米国において精 力的に取り組まれている住宅地開発のマネジメント手法について理 論的・事例的に分析し、それを日本において積極的に参考・応用す るための要点と課題を検討することを目的とする。なお、ここでい う住宅地マネジメントとは、住宅地の企画・整備から維持・管理に いたる全ての事業を継続的・計画的に遂行することをいい、開発マ ネジメントとは、住宅地を計画し整備する開発段階における事業経 営あるいはプロジェクト運用を指している。

近年の日本は、市場原理・競争原理の徹底による所得格差や少子 高齢化・過疎化による地域格差などが明るみになりつつあるが、そ のような複雑な格差問題を社会的にいかに解決するかの糸口はほと んど見えていない。また、現在の公営住宅やUR 賃貸住宅は、自治 体の財政難や事業採算性の中で現在の社会状況に必ずしも十分には 対応できておらず、新たな公共的住宅のマネジメントの担い手とし ての NPO の育成が喫緊の課題となっている。一方、日本よりも深
刻な格差問題を抱える米国では、社会福祉サービスのアフォーダビ リティを高めるべく、生活環境レベルやコミュニティ・レベルで の対策が進んでいる。特に、アフォーダブル住宅の供給という社会 的要請とともに古くから住宅事業を手掛けるNPO が発達し、既に 大きな成果を挙げている。そのため、日本においても米国 NPO に 注目した関連研究は数多い。例えば、NPOによるコミュニティ・ ベースド・ハウジングについて一連の研究を行った平山洋介は、低 所得者へのアフォーダブル住宅の供給を通じてコミュニティの改善 を目指すニューヨークの CDC (Community-based Development Corporation）の発展を解説しながら、日本におけるNPOによる 住環境整備の発展には CDC に関わる制度や技術への参照だけでな く、社会・経済・政治における CDC の位置と性質に注目すること

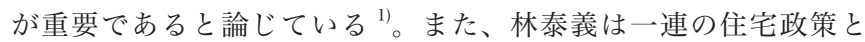
NPO に関する調査研究を踏まえ、日本では「当面 NPO が住宅市場 で量的に大きなシェアーを占めるとは考元難い」としながらも、将 来の住宅関連 NPO の普及イメージとして「地域密着型の住宅供給 事業 NPO」を米国との比較を通して提示している ${ }^{2)}$ 。しかしながら、 これまでの研究の多くは住宅関連分野 NPO の活動を支える米国の 政策や制度、補助金の仕組み等といったソフト面の検討に主眼を置 いたものであった。そこで筆者による先行研究では、米国ウィスコ 
ンシン州マディソン市におけるNPO による大型住宅地開発：ツイ ンオークスのケーススタディを行い、どのような住宅地計画がどの ような関係者の協働の中で構想され展開されてきたのか、エスノメ ソドロジー ${ }^{3)}$ の観点から開発主体と様々な評価主体の間のコミュ ニケーションとその成果を詳細に分析することで、NPO が事業主 体となることの居住環境デザインへの具体的な効果と意義を明らか にした ${ }^{4}$ 。

これら既往研究成果を踏まえ、本研究では、米国ニューメキシコ 州サンタフェの大型コミュニティ開発：ティエラコンテンタのケー ススタディを通して、そのプロジェクトがどのような仕組みや工夫 で実施されているのか、開発マネジメント手法を社会・経済・組織・ 建設等の複合的視点から詳細に分析することで、NPO が住宅地の 開発マネジメントにおいて果たしうる役割と課題、そして日本にお ける応用可能性について論考する。

\section{2. アフォーダブル住宅}

前述の通り、日本においても米国のアフォーダブル住宅に関する 研究の蓄積は少なくない。それにも関わらず、アフォーダブル住宅 への取り組みはほとんど具体化していない。そこには社会・経済・ 文化的に様々な背景があろうが、一つの原因として「アフォーダブ ル」という言葉自体への誤解が挙げられる。既往研究の多くが米国 の政策や制度の理解に主眼を置いていたため、アフォーダブル住宅 整備の具体的なプロジェクト内容や供給されている実際の住宅の質 に関する情報は必ずしも十分ではなかった。それが具体的な居住環 境の理解を伴わない曖昧な解釈へと繋がったと考えられる。

「アフォーダブル住宅 (affordable housing)」は、日本において 既に学術用語として浸透しているが ${ }^{5)}$ 、その多くは、「アフォーダ ブル住宅＝貧困層注1)のための福祉支援的な住宅」という理解であ る。しかしながら、米国において貧困層のための支援住宅といえ ば、一般には「パブリック・ハウジング (public housing)」を指し、 基本的に賃貸住宅である。一方、アフォーダブル住宅の対象は、住 宅購買者が生活している地域の平均所得の $30 \sim 100 \%$ というき な幅をもって捉えられ、分譲住宅が中心である。この所得層は確か に低所得ではあるが、貧困層よりも確実に高い層に位置する。例え ば、この所得よりも低い場合には、食料引換券（food stamps）や 低所得者医療扶助制度といった公的プログラムの対象となり、また 給食費の免除等の対象にもなってくる。平均所得の $30 \sim 100 \%$ の 層は、これらのプログラムの対象とはならない。つまり、これらの 所得層こそ居住環境の質の向上に関わる何らかの社会的なサポート が必要なグループであるということが、そもそもの米国における認 識なのである。

つまり、アフォーダブル住宅とは、文字通り「affordable（入手 可能な)」という意味で理解されるべきである。現代的な人権倫理 の観点に立つとき、アフォーダブル住宅は、日本においても社会的 居住環境整備の重要な課題の一つである。

\section{3. 調査方法}

ティエラコンテンタは、サンタフェ都心部の急激な住宅価格の 上昇と急速な都市スプロールを背景とした、民間非営利の特別目 的会社: Tierra Contenta Corporationによるアフォーダブル住宅
のための大型開発である。アフォーダブル住宅供給だけでなく商 業施設や福祉施設の整備も行い、Public-Private Partnership（以 下、PPP) による所得階層混在型 (mixed-income) のコミュニティ 開発の先駆的事例として米国で高い評価を得ている。1999 年には American Planning Association のプランニング・アワードを授賞 している。

調査方法としてまず、開発計画がどのように構想され展開された のかを把握するために、プロジェクト推進において中心的な役割を 果たしている人物へのヒアリング調査を行った主2)。その主な内容 は、開発の背景や経緯、実施方針と体制、計画コンセプト、デザイ ン・プロセス、補助金活用の工夫、開発マネジメント手法、NPO • 民間営利企業の役割や活動内容、意思決定・合意形成とその調整方 法、設計基準と設計指標、現状と課題等である。また、開発プロセ スをより詳細に理解するためにメモ・図面・報告書などの関連資料 を可能な限り入手した ${ }^{6 \sim 10)}$ 。

4. ケーススタディ

\section{4-1. ティエラコンテンタの概要}

サンタフェは全米でも屈指の観光都市であり、それゆえ、低所 得者層の収入と一般市場住宅の価格との間に深刻な開きが生じてい る。図 1 に示すように、一般市場住宅の平均価格はここ数年で大 きくつり上がっている。例えば、2004 年の平均価格 $\$ 375,000$ の 住宅を購入するためには一世帯当たり $\$ 90,000$ から $\$ 100,000$ の収 入が必要といわ机るが、サンタフェの平均所得は $\$ 60,000$ 前後であ り、その世帯が支払い可能な住宅価格も $\$ 222,000$ である。一般に 米国では、このような大規模なアフォーダブル住宅供給の必要が生 じた場合には、そのほとんどで連邦住宅都市開発省 (Department of Housing and Urban Development /以下、HUD) の HOPE 制 度の資金が投入される。これらの公設住宅はいくつかの一般市場価 格住宅と組み合わされて供給されるものの、基本的に既存の高層の 公設住宅を取り壊し、再びその土地で集約的に建設される。この方 法では、必ずしも郊外の戸建住宅が軒を並べる環境のスケールに適 したものを実現することはできない。

ティエラコンテンタは、サンタフェ市が 1992 年に郊外の広大な 土地を取得し（図 2)、マスタープラン作成を主導、土地を購入し た Tierra Contenta Corporation が開発マネジメントの基幹を担い、 区画ごとにNPO および民間営利企業へ工事を発注するという手法 で、現在も継続して開発が進められている。25年の開発計画であり、 計画人口としては 10,000 人規模のものとなる（図 3)。

\section{4-2. 計画・開発の経緯}

サンタフェでは、1990 年代初めに、セカンドハウスの取得を目 的とする新たな高所得者層と定年退職者の都心部における急速な移 住が始まった。その結果、サンタフェ全体の住宅価格が高騰し、人 口の約 8 割が平均市場価格の住宅を購入することができないとい う状況となった。そしてそれは、急速で無計画な住宅地のスプロー ルを生み出し、郊外は治安的・衛生的に問題のある環境へと変わり はじめた。このような中、サンタフェ市は、1991 年のサンタフェ 南部地域での広大な土地の抵当物受け戻しをきっかけに、住宅価格 の上昇と都市スプロールに対応するためのアクションプランの具体 化に取りかかり、表 1 に示す内容の戦略的アフォーダブル住宅計 


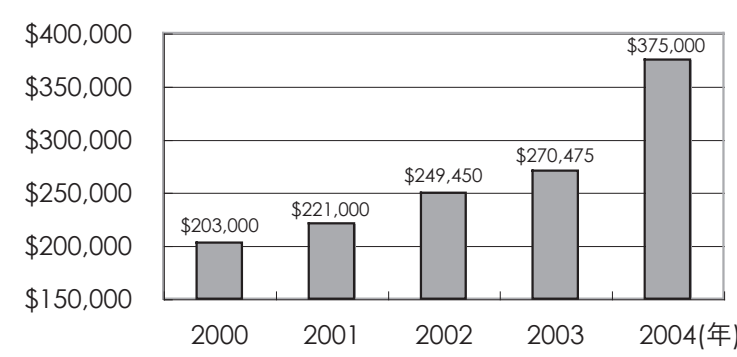

図 1 サンタフエ郡の一般市場住宅の平均価格の推移

1）3年以上をかけて新たに $700 世$ 帯のアフォーダブル住宅を 創出する

2) アフォーダブル住宅に関する公共政策とアクションプラン の実行の中心として、自治体やNPOなどからなるコンソー シアム:Santa Fe Affordable Housing Roundtableを 発足する

3）プロジェクトとそれに関わる職員配置のための大規模な資 金調達に取り組み、地元のアフォーダブル住宅を建設・販 売する非営利のディベロッパーの事業能力を高める

4) 分割払い頭金補助 (down-payment assistance) にも利 用可能な低価格融資と助成金の財源を確保する

5）その財源は、連邦住宅都市開発省(HUD)のHOME制度を 中心に検討する

6）サンタフェの土地不足とそれに伴う不動産価格の高騰を、 アフォーダブル住宅の開発が可能なレベルの状態へ収束 させる

表 1 サンタフェの戦略的アフォーダブル住宅計画の概要

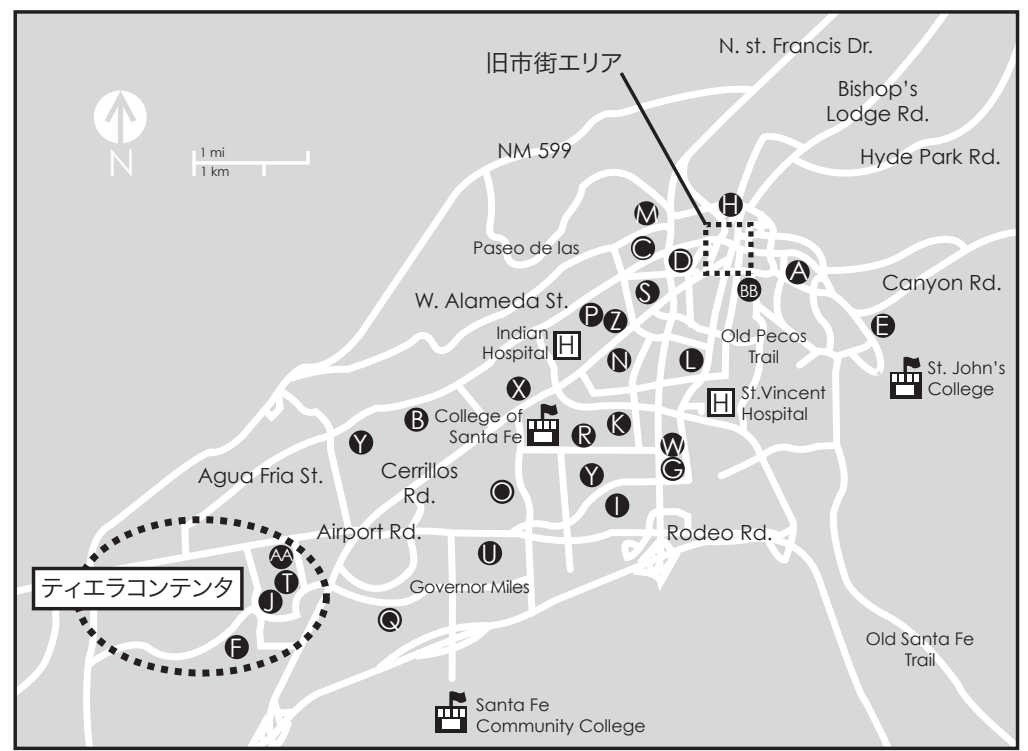

A Acequia Madre

B Agua Fria

C Alameda Middle Schoo

D Alvord

E Atalaya

F Atalaya

G Capshaw Middle School

$G$ Capshaw Mid

Carlos Gilbert

Chavez

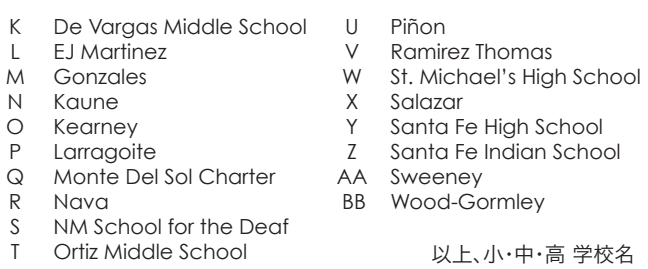

T Ortiz Middle School

図 2 ティエラコンテンタの立地

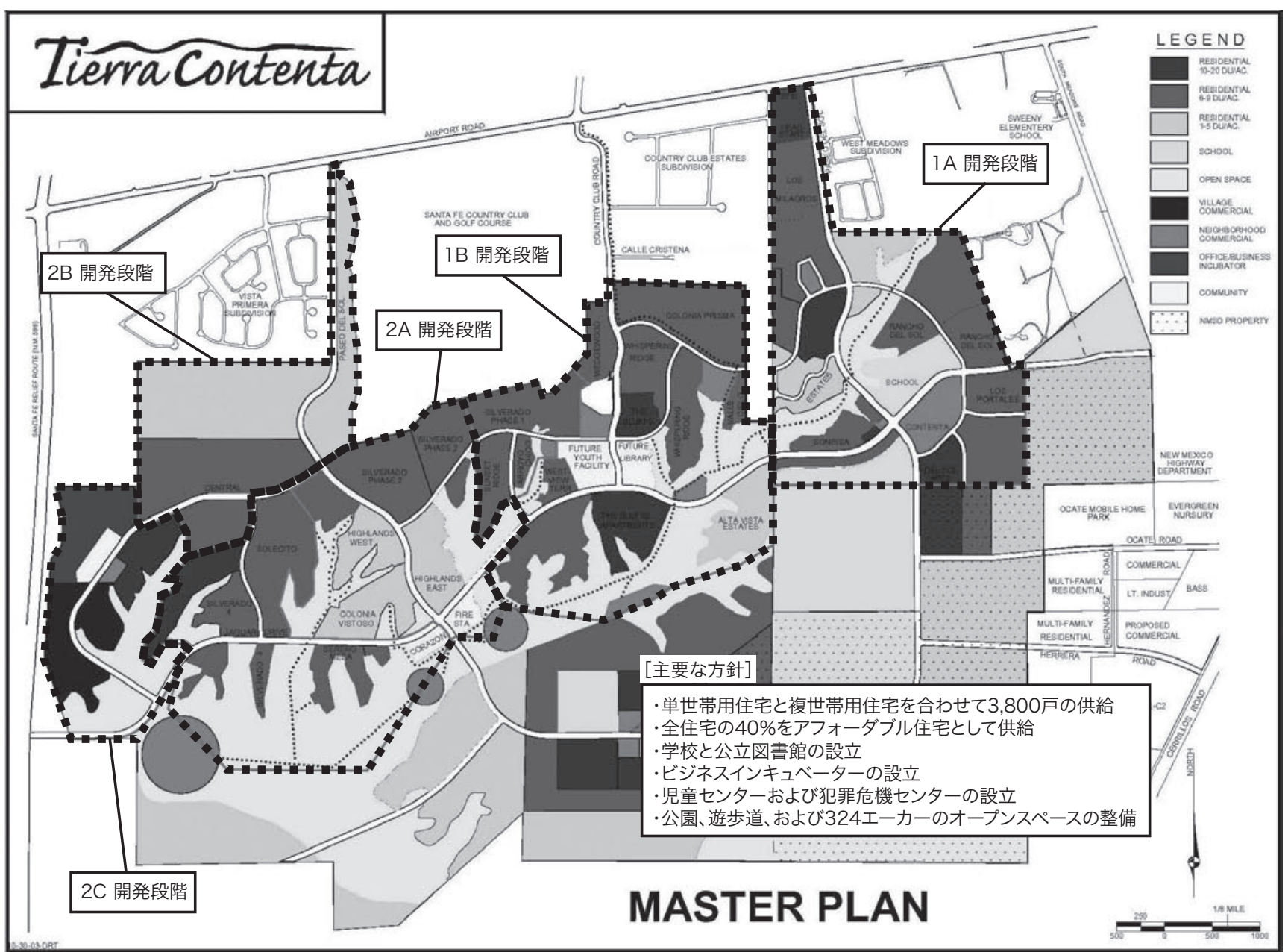

図 3 ティエラコンテンタのマスタープラン (Tierra Contenta Corporation より提供されたマップヘ一部加筆) 
画を策定した。

Santa Fe Affordable Housing Roundtable は、サンタフェ市の 先導で、米国でアフォーダブル住宅の供給を手掛ける最も大きな NPO の一つである Enterprise を中心に、市と郡の当局、9つの非 営利の住宅関連機関からなる連合注3) として 1991 年に設立された。 1992 年からの 3 年間で住宅補助のための $\$ 55,000,000$ の資金を政 府や民間セクターから調達し、その安定した資金調達能力と活動が 評価され、1996 年には Innovations in American Government を 授賞している。

ティエラコンテンタの開発は、サンタフェ市が 1992 年に 863 エーカーの土地を $\$ 6,300,000$ で購入したことから始まった。条例 により市による開発のための直接的な資金割り当てが禁止されてい るため、Santa Fe Affordable Housing Roundtable が中心となって 1993 年に Tierra Contenta Corporation を設立し、そこへ土地が 売却された。売却金は、Tierra Contenta Corporation が各々の区 画ごとディベロッパーへの売却で得る収入を当てる、サンタフェ市 への分割払いとなっている。

また、ティエラコンテンタの地域は、全住戸の $40 \%$ をサンタフェ の平均所得の $80 \%$ 以下の所得者層へ供給する開発でもって、サン タフェ市へ併合される取り決めとなっている。この併合合意におい て、サンタフェ市は同時に水利権の許可免除を開発に対して取り決 めたとされている。現在の条例に従えば、水利権を得るためには、 ティエラコンテンタの場合、 $\$ 4,000,000$ から最大 $\$ 8,000,000$ を市 へ支払うことになるのだが、これまでそれが免除されることが、ディ ベロッパーに対してティエラコンテンタでアフォーダブル住宅の 供給を手掛ける大きなインセンティブを与えてきた。しかしながら 2007 年現在、この水利権を巡りサンタフェ市と Tierra Contenta Corporation は法廷で争っている。詳細は「4-5, 現状と課題」に おいて後述する。

\section{4-3. 組織と運営}

Tierra Contenta Corporation は、専務を含む 3 人のスタッフが 勤務し、販売や金融、デザイン - 開発 - 建設、マネジメントおよび 法律、自治体（サンタフェ市）という４つの分野からなる 15 人の 理事によって管理運営されている。ティエラコンテンタの開発のみ を手掛けるNPO としての主な活動使命は、(1) 開発を手掛けるディ ベロッパーの選出、(2) 主要なインフラの整備、(3) アフォーダブル 住宅供給の誘導・指導、(4) サンタフェ市への $\$ 6,287,000$ の土地ロー ンの返済、(5) 公園やオープンスペース、パブリックスペースのた めの土地提供、である。

Tierra Contenta Corporation の運営資金は、ディベロッパーへ の土地販売から得られるものが主であり、年間約 $\$ 333,000$ である。 開発初期においては、HUD による資金援助が大きな役割を果たし た。Tierra Contenta Corporation は、インフラ整備のために HUD から $\$ 1,500,000$ の特別目的助成金を獲得した。HUD の HOME 制 度と連邦政府の低所得者住宅向け投資税額控除制度 (Low Income Housing Tax Credit /以下、LIHTC) 注4) は、米国において民間ディ ベロッパーによるアフォーダブル住宅建設への参画を推進するため に効果を発揮してきた政策である。

ティエラコンテンタの重要なパートナーシップとして、NPO で ある Santa Fe Community Housing Trust と Homewiseは、アフォー
ダブル住宅の建設と販売を手掛けるだけでなく、低所得者層住宅購 買者の収入に関する適性審査、住宅購買者へのトレーニングの実 施、分割払い頭金補助等の金融サービスの提供を行っている。同 じくNPOの St. Elizabeth’s Shelter は、ホームレス世帯の過渡期 の住まいとして8つのアパートメントを建設している。Casas de Buena Ventura は地元の非営利の住宅事業機関であり、LIHTC を 活用し低賃貸料のアパートメントを建設する営利企業とジョイント ベンチャー事業を手がけている。また、Affordable Housing Trust Fund は、Santa Fe Affordable Housing Roundtable と Santa Fe Community Housing Trust の運営管理によって、アフォーダブル 住宅を手掛ける非営利ディベロッパーへの助成金もしくはローンを 提供する信託基金である。主として、低所得者層住宅購買者のため の分割払い頭金補助へ割り当てられている。なお、審査ではコンペ テイション方式が採用されている。

関連するサンタフェ市によるアフォーダブル住宅整備への取 り組みとしては、コミュニティ開発包括補助金 (Community Development Block Grant /以下、CDBG）による分割払い頭金 補助プログラム、および、Santa Fe Community Housing Trust と Neighborhood Housing Services of Santa Feによって運用されて いる住宅購買者教育プログラムが挙げられる。これらのプログラム と協調して、New Mexico Mortgage Finance Authorityは、低所 得者層住宅購買者への分割払い頭金補助ローンを提供している。

\section{4-4. 開発マネジメント手法}

ティエラコンテンタの整備は、Tierra Contenta Corporation が 直接工事を手掛けるのではなく、分割した区画を NPO および民間 営利企業へ売却し、彼らが実際の住宅建設を手がける仕組みとなっ ている。例えば、Habitat for Humanityは、個々の宅地に対して アフォーダブル住宅の建設・販売を行っているNPO の一つである。 筆者は先行研究 ${ }^{4)}$ において、Habitat for Humanity によるウィスコ ンシン州マディソンのツインオークス住宅地開発のケーススタディ を行ったが、そこで詳細に解説した住宅地計画が、ティエラコンテ ンタの各区画で実践されているわけである。ただし、ティエラコン テンタはそもそも自治体が先導し、Tierra Contenta Corporation が全体計画を推進しているのに対し、ツインオークスは Habitat for Humanity 独自の開発、つまり NPO による完全な民間事業とい う点で性格が異なる。

マスタープランは、ニューアーバニズムの提唱者の一人である P. カルソープの協力のもと策定された。P. カルソープは $1 \mathrm{~A}$ 開発 段階に携わったものの、サンタフェ郊外への公共交通サービスの 計画見通しがないことから、公共交通志向開発（TOD: Transport Oriented Development）の実現が難しいと判断しそれ以降の開発 には関与していないが、その住宅地計画は、「地区内の移動は地区 内道路のみを使ってでき、明快で、覚えやすく」とし「直線的で見 通しのよい地区内道路に面して住戸を配する」というニューアーバ ニズムの方針にある程度忠実な内容となっている ${ }^{11)}$ 。1 A 開発段階 の住宅地計画と供給主体を図 4 に示す。

P. カルソープが主に手がけたのは設計指標（design guidelines） の作成 ${ }^{7)}$ であるが、一般的に設計指標と設計基準 (design standards）とでは、その効力が大きく異なる。設計指標は、あく までその採用を推奨するものであって、強制的な遵守を求めるも 
のではない。ティエラコンテンタでは、最初の開発段階（1A）で は前者が採用され、その後の開発段階（1B～2C）では後者が定め られたのだが、Santa Fe Affordable Housing Roundtable を基盤と する Tierra Contenta Corporation が指導力と機動力を発揮し、1A 開発段階において設計指標がほぼ完璧に守られた。その成果とし て、開発地域全体のほとんどのアフォーダブル住宅で 2 台分のガ レージを設けているとともに、建物のパターンやマテリアルも統 一され、アフォーダブル住宅のデザインが一般市場住宅と大きく
異なることのない街並みを実現している（図 4 内写真参照)。この Tierra Contenta Corporation が設計を審査し指導することにより 得ら机る効果と効率が、1B 開発段階以降の設計基準の策定へと繋 がることとなった。

ティエラコンテンタにおける設計基準は、工事を効率的に展開す るために大きな役割を果たしている。一般にディベロッパーは、工 事に先立ち開発計画と建築許可の承認を市から得なければならない が、ティエラコンテンタの設計基準は市から建築許可の委任を受け

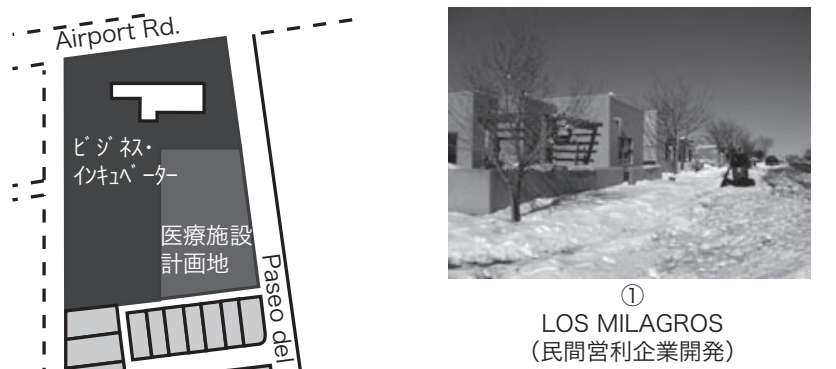

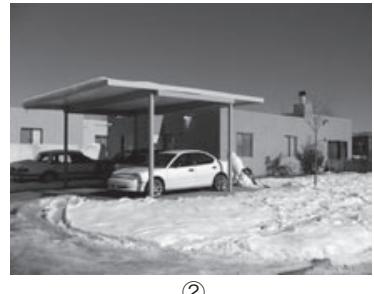

LOS MILAGROS (民間営利企業開発)

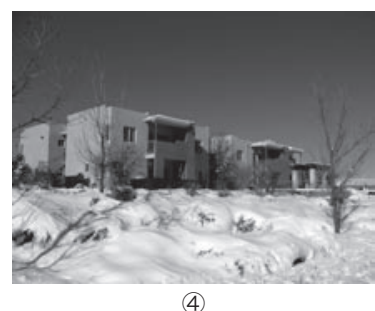

VISTA LINDA APARTMENTS (NPO開発)

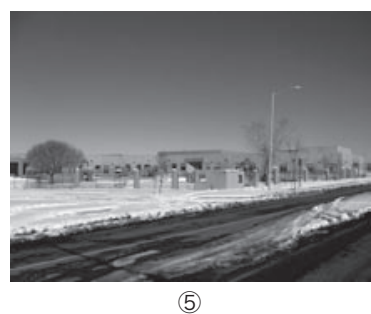

CESAR CHAVEZ 小学校
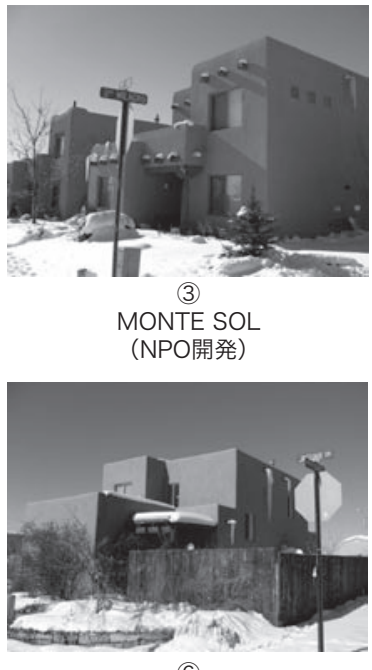

(6)

ARROYO GRANDE （民間営利企業開発）

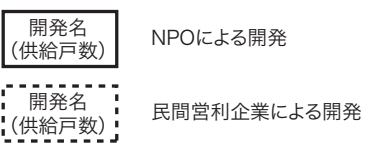

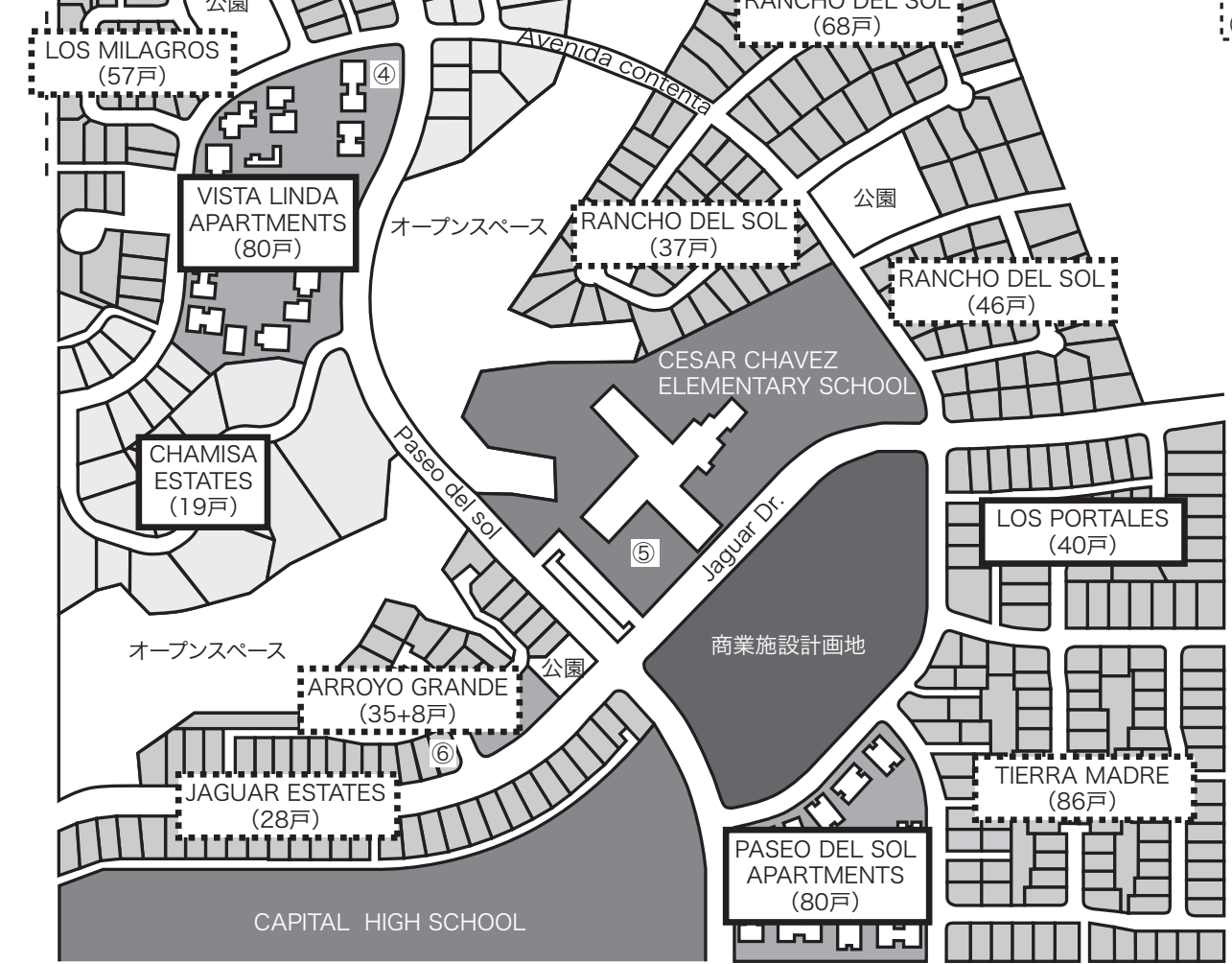

図 $41 \mathrm{~A}$ 開発段階の住宅地計画と供給主体 
ており、ティエラコンテンタの理事会による審査によりその手続き の大部分を省略することができる。つまり、ディベロッパーは、ア フォーダブル住宅を供給するうえで大きな動機づけが与えられてい るのである。マスタープランや設計基準によって既に計画が緻密に なされていることで開発承認が比較的早く得られるからである。さ らに、開発負担金の免除等によって土地の価格が同様の土地の市場 価格にくらべ10～15\%ほど低くなることも大きく働いている。

このような動機づけを基盤に、Tierra Contenta Corporation が さらにディベロッパーの土地購入価格と低所得者の住宅購入価格 を抑えるために活用しているのが抵当補助金である。抵当補助金 を中心とした開発マネジメント手法のダイアグラムを図 5 に示 す。この手法によって、サンタフェでの一般市場住宅（ツーベッド ルーム）の価格が約 $\$ 200,000 ％ 300,000$ であるのに対し、ティ エラコンテンタでは、ほとんどのアフォーダブル住宅（ツーベッ ドルーム）で平均 $\$ 160,000$ の価格を実現している。なお、サン夕 フェの平均所得 $80 \%$ 以下の所得者層であれば、おおよそ単世帯用 住宅で $\$ 150,000$ から $\$ 185,000$ の間が購入可能な価格である。低 所得者層の住宅購買者の多くは加えて、一住宅当たり $\$ 5,000$ から $\$ 30,000$ の分割払い頭金補助金を受けることができる。また、16 戸の住宅は土地信託制度により建設されており、平均 $\$ 80,000$ とい う驚異的な低価格を実現している。

サンタフェは前述した通り、全米でも最も人気の高い居住 地の一つであることから、高所得者層の移住者が不動産を買収 し、既存住民が転出、それが不動産価格を上昇させ、高級住宅化 (gentrification) を進めてきた経緯がある。よって、長期にわたっ て安定した所得階層混在型コミュニティを維持するためには、居 住者の定住が必要不可欠である。これに対して、Tierra Contenta Corporation は、低所得者層の住宅購入者への抵当補助金による価 格割引の引き換えとして、7 年を越えて 10 年間で段階的に免除さ れる不動産への $\$ 6,000$ の留置権への同意を条件に、アフォーダブ ル住宅を提供している。その契約期間に住宅を売却する場合には、 住宅所有者は $\$ 6,000$ の一部を Tierra Contenta Corporation へ支払 わなければならない義務を負うものである。留置権の目的は、所得 階層混在型コミュニティを維持すると同時に、低所得者層が目先の
売却利益に屈して安易に不動産を手放してしまうリスクを防ぐこと にある。

\section{4-5. 現状と課題}

ティエラコンテンタでは、1995 年に住宅供給が始まって以来、 当初の計画よりも約 $10 \%$ 上回るペースで年間約 150 の新築住宅が 整備されている。例えば、2003 年末時点で 1,393 戸が供給され、 分譲住宅が 1,036戸 $(74 \%) 、$ 賃貸アパートメントが 357 戸 (26\%) であった。分譲住宅では 368 戸がアフォーダブル住宅、668 戸が 一般市場住宅である。また、アパートメントは全て低所得者層のた めのものである。アフォーダブル住宅の創出という意味では、一応 の成功をみている。

しかし現在、計画当初にはおそらく想定できなかった問題に直面 している。ティエラコンテンタの事業計画・マスタープランおよ び Tierra Contenta Corporationの設立は、サンタフェ市に先導さ れたものであるにも関わらず、Tierra Contenta Corporation はサ ンタフェ市へ訴訟を起こし、2006 年 8 月 22 日に連邦地方裁判所 へ告訴を提出したのである。それは、2005 年に定められた建設許 可に先立って水利権の許可を得ることを新たに取り決めた条例に対 するものである。条例が適用されれば、費用が直接に住宅購買者の 負担へと繋がることになる。Tierra Contenta Corporation の主張 は、市はティエラコンテンタを併合すると同時に水道サービスを提 供することに既に同意しており、ティエラコンテンタはこの条例の 適用を免れるというものである。また、水利権の許可申請によって 生ずる開発の遅延についても同様に損害補償を求めている。Tierra Contenta Corporation は、この条例はティエラコンテンタのよう な大規模プロジェクトには不向きな内容であり、そもそもティエラ コンテンタの開発は莫大な水を購入できるほどの事業スキームには なっておらず、ディベロッパーによるアフォーダブル住宅供給を後 退させると強く主張している。一方の現在のサンタフェ市長は、ティ エラコンテンタが条例の適用から除外される理由と併合合意とは関 係がないと反論している。この訴訟は、ティエラコンテンタの今後 の事業継続自体をも左右する問題であるが、2007 年 1 月時点では その決着の見通しはついていない。

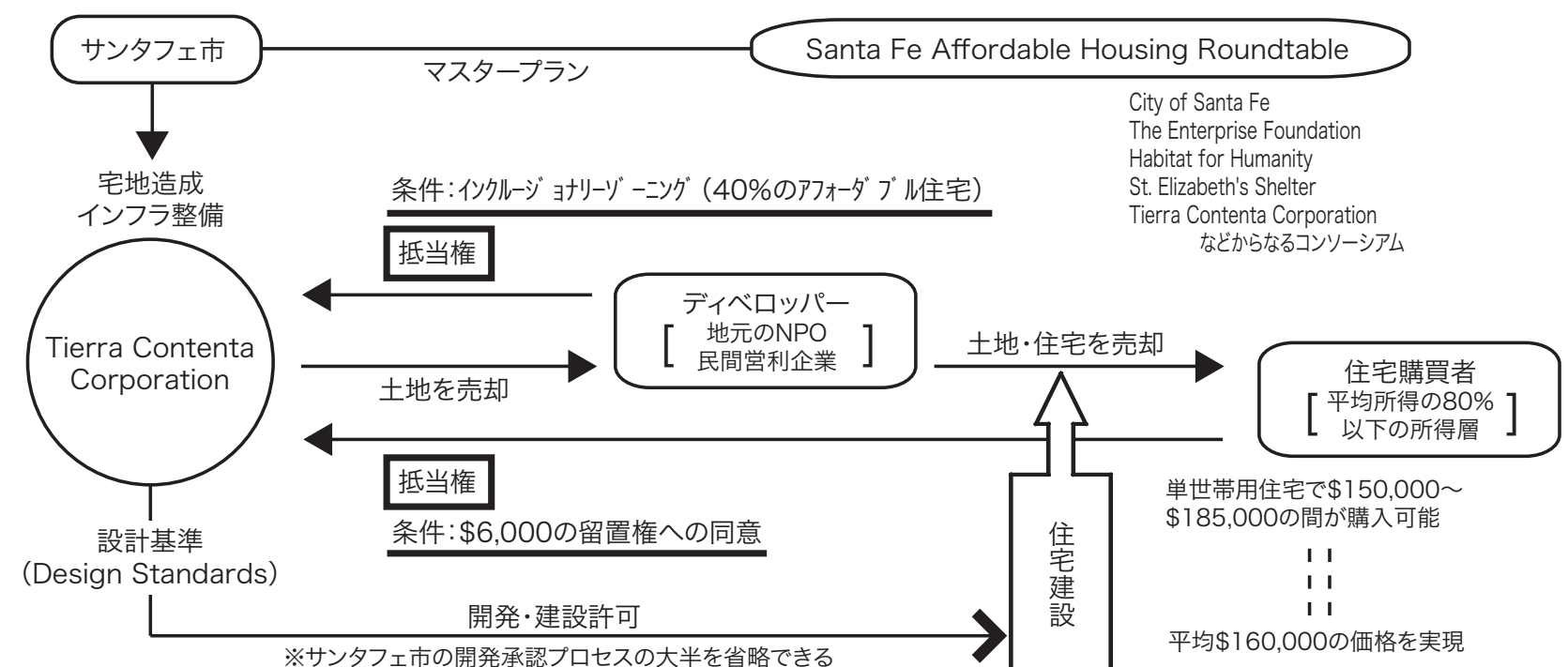

※サンタフェ市の開発承認プロセスの大半を省略できる

平均 $\$ 160,000$ の価格を実現

図 5 テイエラコンテンタの開発マネジメント手法 


\section{5. 考察}

以上のケーススタディから、日本における NPO による住宅地の 開発マネジメントの可能性を検討する上で、二つの論点が得られ た。一つは「問題中心的ラウンドテーブル」であり、もう一つは「プ ロジェクトベースの特別目的型 NPO」である。

5-1. 問題中心的ラウンドテーブル

ティエラコンテンタの実現において、Santa Fe Affordable Housing Roundtable が一つの大きな役割を果たしているが、この 組織を日本において参照する上で重要なのは、それが NPO、自治 体、財団、民間営利セクターで構成されており、それぞれの制度的 志向性注5) のコラボレーションで具体的な活動が展開されていると いう点である。つまり、ある特定の明確な地域課題の解決へ向けて のPPP の具体化組織であるということである。日本でも地域課題 の解決へ向けての評議会やワークショップが開催されているが、自 治体 vs 住民」というある種の対立関係の中で、いわゆる“ガス抜き” 的に行われていることも少なくない。公共の福祉を目指すのであれ ば、二元的な参加の枠組みではなく、本来の公共の意味による多元 的な組織の構成が必要である。

しかしながら、複数の制度的志向性をもつた主体の参加があれば それでラウンドテーブルが成立するわけでは全くない。まず大前提 として、ラウンドテーブルの目的・目標としての地域課題が具体 的に把握されていること、つまり、本質的に問題中心的 (problembased)であることが必要である。日本の “ガス抜き”的ワークショッ プは、いったい住民参加によって具体的にどのような課題を解決す るのかが明確でないままに、集会だけが手続き的に開催されている ことが問題なのである。

また、ラウンドテーブル設立自体が誰の発案でいつどのように立 ち上げられるのか、その夕イミングも重要である。これが適切でな ければ、例えばサンタフェにおいても、ティエラコンテンタ開発は 実現されなかったに違いない。サンタフェでは、その適切な夕イミ ングを見出し、多元的構成を目指して呼びかけを積極的に行った自 治体のイニシアチブ能力が高かったと評価できょう。

多元的構成員によって組成されたラウンドテーブルが、地域課題 の解決へ向けて有意義な提言や提案を行っていくために次に重要な 点が、新たな活動主体としての制度的志向性である。先に、ラウン ドテーブルの設立は問題中心的であるべきと論じたが、多元的な制 度的志向性をもったメンバーにより構成されるラウンドテーブル自 体の制度的志向性が、その問題解決の質を大きく左右するといって もよいだろう。そのランドテーブルとしての制度的志向性は、財政 的あるいは政治的な動向に大きく影響される自治体に対して、そし て時には自己中心的な要求を民主主義的（多数決的）に主張する住 民に対して、地域課題の解決という使命とその達成への理性を持っ た独立的なカウンターパートである必要がある。そうでなければ、 公共を体現した組織とその活動とはなり得ない。

なぜなら、例えばラウンドテーブルが国や自治体の外郭団体等で ある場合には、日本における例を出すまでもなく、人的・業務的・ 資金的側面において国・自治体への従属的な関係からは完全に逃机 ることができないため、ラウンドテーブルの意思決定における公共 的中立性の低下を招くことが指摘できる。また、資金調達面におい て積極的な自助努力が期待できないことも、組織と活動の質にかか
わる大きな問題である。Santa Fe Affordable Housing Roundtable の精力的な資金調達は、単に活動資金の確保という意味だけでな く、それを通しての組織自身による様々なノウハウの蓄積と、他の 民間セクターとの協働による地域ボトムアップ型ネットワークの構 築という成果へと繋がっており、第 4 章で具体的に示してきたよう に、それらがティエラコンテンタの事業スキームの基盤となってい るのである。また、過度に住民参加を重視したラウンドテーブルで あっても、公共的中立性は低下すると考えられる。いうまでもなく、 公共的な取り組みは、必ずしも社会的マジョリティのニーズに応え ることではない。サンタフェを例にとると、社会的マジョリティは 高級住宅化を担っている移住民である。現実として、彼らからは決 してアフォーダブル住宅に関するラウンドテーブル設立の声は上が らなかったわけであり、Santa Fe Affordable Housing Roundtable が彼らから独立していなければ、彼らが所有する資産の価值に少な からず影響を与えるティエラコンテンタの事業を実現することは困 難であったといえよう。

\section{5-2. プロジェクトベースの特別目的型 NPO}

日本の NPO も、その組織数だけを見れば大幅に成長したといえ る。しかし、Tierra Contenta Corporationのように大規模な住宅 事業を手掛けることのできるNPO は皆無といってもよい。その理 由の一つとして、日本の NPO の資金調達手段が非常に限られてい ることが挙げられよう。米国では、特にアフォーダブル住宅の整備 を中心に、HUDによる CDBG や HOME 制度をはじめとする潤沢 な補助金があるのに加え、LIHTCによる民間セクターの積極的な 投資・融資の誘導が実施されてきている。これらに比べると、日本 の住宅事業 NPO の活動促進へ向けた制度的・政策的支援は貧弱で あるといわざるを得ない。

だが、米国の政策が必ずしも直接日本へ輸入できるわけでもな い。NPO という社会的・文化的土壌がなく、NPO がボランティア 団体の一種のように時には当事者さえも認識している日本におい て、全てのNPO にはじめから大きな使命のもと永続的な活動を求 めることは難しい。そして、そのような体質の現状の日本版 NPO に対して、自治体であ机民間であれ、寄付や融資を行うことは非 常にリスクが大きいことでもある。そこで本節では、“プロジェク トベース (project-based) ”をキーワードとして、日本における NPO による住宅事業の戦略的展望を提案的に論考したい。

公共事業をプロジェクトベースで民営化するという方法は、現在 の日本でも既に PFI (Private Finance Initiative) が導入されている。 歴史は浅くその導入の是非についての評価はまだ定かでない部分が 多いが、1999 年の『PFI法（民間資金等の活用による公共施設等 の整備等の促進に関する法律)』の施行以来 8 年が経過し、多くの 事業が計画・実施されている。PFI の詳細な解説は省略するが、民 間企業の構成員の出資によって設立された特別目的会社 (SPC) が 一種の元請けとなり、構成員の企業へ各種業務を発注し、公共サー ビスを実現する仕組みである。

しかしながら、筆者は既往研究を通して、現在の日本版 PFIにお ける事業計画において、VFM（Value For Money）の最大化とリス クの分散化を目的とする構成員の制度的志向性とその構成員のみに よる意思決定が施設デザインの質の低下をもたらす問題を指摘して いる ${ }^{12)}$ 。そして、ツインオークス住宅地開発を取り上げた先行研 
究では、NPO が意思決定の中心として事業を推進するシステムが 経済的理由以上の居住環境デザインにおける多面的なリスクの低減 に繋がっていることを明らかにしている ${ }^{4)}$ 。うま、あくまで SPC は “公共”事業を成立させるための主体であるから、その事業計画 の意思決定は、それぞれの構成員の自己利害の関係で状況づけられ るものではなく、それを越えた先の地域課題の解決という使命から の理性的視点を備えたものであるべきと同時に、資金調達のプライ オリティを検討できるものでなければならない。よってここから、 “SPC を非営利化する”という着想が導かれる。プロジェクトベー スであれば、ある程度の期間を前提に完結した採算計画が立てられ るため、民間セクターから NPO への投資・融資の可能性も高まる と考えられる。そして、構成員としての営利企業の参画へのインセ ンティブは、米国の LIHTC に近いシステムを導入することで与え ることが可能であろう。

日本の NPO と米国のそれとの体質的な差異は、既にその呼称に 明確に表れている。日本では Non-Profit Organization の省略とし てNPO が用いられているが、米国では Not-for-Profit Corporation あるいは Non-Stock Corporation と表現されるほうがむしろ一般 的である。“Non-Stock” な企業であるだけであって、事業の遂行能 力においては営利企業と全く同等であることが求められ、それが当 然と認識されているのである。つまり、非営利の立場からプロジェ クトを実行し、そのために必要なスタッフを雇用する能力を持ち、 柔軟な資金調達の機構を備えている企業なのである。したがって、 SPC を非営利化するという手法は、既存の日本版 PFI を活用して、 Non-Stock Corporation を育成しょうという戦略でもある。

また、ティエラコンテンタの開発マネジメント手法の特徴として 解説した、設計基準による建築許可の委任は、日本においても有効 なツールであろう。いわゆる建築確認申請の一部委任であるが、日 本の民間委託とはプロジェクトベースであるという意味で全く性格 が異なり、いわゆる耐震強度偽装問題の中で露呈した企業能力を超 える処理案件数や審査の不正確さの問題は十分回避できると考えら れる。また、現在の日本版 PFI の仕組みで SPC へ建築許可の委任 を行うとその営利的な志向性のため全く機能しないことは明らかで あるが、ティエラコンテンタのような理事会（board）を有した非 営利特別目的会社（Non-Stock SPC）であれば、最終的な許可は自 治体が出すにしても、適切に機能し事業の迅速な展開へと繋がるこ とが期待できる。

\section{6. まとめ}

実は日本において、問題中心的ラウンドテーブル」と「プロジェ クトベースの特別目的型 NPO」の潜在的な可能性を少なからず示 すプロジェクトが既に動いている。詳細については現在調査研究中 であるが、富山市において地元の設計事務所や建設会社・地主組織 が協力してNPO を立ち上げ、NPO 自らが地元の銀行から資金を 調達、分譲住宅地開発を行っている『田園住宅開ヶ丘基盤整備事業』 である ${ }^{13)}$ 。事業主体である『NPO 法人里山俱楽部』の設立主旨は「ま ちづくりの推進を図る活動」「環境の保全を図る活動」となってい るが、実際は分譲住宅地開発を実現するために組織されたプロジェ クトベースの NPO である。2007 年 5 月時点では宅地造成の段階 でありこの事業への評価はまだ可能ではないが、農村振興という地
域課題の解決へ繋げる新たなコミュニティの創出を目指していると いう意味において、非営利特別目的会社（Non-Stock SPC）の社会 的な要請を示唆するものである。

最後にまとめとして指摘しておきたいが、この非営利特別目的会 社（Non-Stock SPC）は、あくまで自治体から完全に独立していな ければならない。公共事業に関わる限り何らかのかたちで自治体側 の影響を受けざるを得ない。特に開発計画初期には予測不可能な事 態が生じた際に、社会問題の解決という使命と理念のもと事業の妥 当性を評価し判断できる立場を維持できる体質が必要である。本研 究で Tierra Contenta Corporationによる水利権に関する訴訟を紹 介したが、自治体に対して正面から訴訟が起こせないような組織で は、かつての第三セクターのような不明瞭な民営化と同じ失敗へと 繋がることはいうまでもない。

なお本研究は、国土交通省・土地総合研究所平成 18 年度土地関 係研究推進事業によって行われたものの一部である。

注

注 1) OECD : 経済協力開発機構（http://www.oecd.org/）は全家計平均所得 の半分以下の所得である家計を貧困層と定義している。また、国連による 絶対的貧困層とは「1日 1 ドル以下で生活している層」を指す。

注 2) Ed Rosenthal 氏：Enterprise ニューメキシコ・オフィス・ディレクター (2007年 1 月 3 日実施)、および、James S. Hicks 氏：Tierra Contenta Corporation エグゼクティブ・ディレクター（2007 年 1 月 4 日実施） 一 ヒアリングを行った。

注 3) 参加構成員:City of Santa Fe, The Enterprise Foundation（Enterprise Community Partners), Esperanza, Habitat for Humanity, Life Link/ La Luz, Neighborhood Housing Services of Santa Fe, NM Coalition to End Homelessness, Open Hands, St. Elizabeth's Shelter, Santa Fe Civic and County Housing Authorities, Santa Fe Community Housing Trust, Sustainable Communities, Inc., Tierra Contenta Corporation

注 4) 低所得者向け住宅の所有者や出資者に対して、連邦税から投資減税を 行うもの。銀行や投資会社によるNPO が行う開発プロジェクトへの投 資を促す仕組み。所得控除（tax deduction）とは、所得金額からそれ を差し引き課税標準額（taxable income）に税率を掛けて税倩務額（tax liability）を計算するものであるが、税額控除（tax credit）はその税金を 直接少なくするため、民間企業にとっては所得控除よりも大きなメリット がある。

注 5) 制度的志向性とは、社会的な制度で設定された仕事や役目に対する人夕 の志向性のことをいう。文献 3）を参照。

参考文献

1) 平山洋介, 非営利住宅事業のジレンマと展望 世界都市/ニューヨークの 経験から，住宅，日本住宅協会，52(10)，pp.11-17，2003.10

2）林泰義，住宅市場と NPO の普及可能性，都市住宅学，pp.40-46，1998.12

3）森傑，エスノデザインメソッド - 人々のデザインのやり方 -, 舟橋國男編著, 建築計画読本，大阪大学出版会，pp.273-298，2004

4）森傑，民間非営利組織による大型住宅地開発の計画論に関する研究一米国 ウイスコンシン州のツインオークス・プロジェクトに注目して一, 日本建築 学会住宅系研究論文報告会論文集，第 1 号，pp.7-16，2006.12

5）日本都市計画学会監修·都市計画国際用語研究会編, 都市計画国際用語辞典, 丸善, G6, 2003

6) The Enterprise Foundation (Enterprise Community Partners), Affordable Housing Supply, Demand And Pricing In Santa Fe County: A Report Prepared for Tierra Contenta Corporation, 2005.5

7) Mazria Associates, The Flance Company, Calthorpe Associates and COPA, Design Guidelines for Phase 1A of Tierra Contenta Planned Community, 1994.11

8) Tierra Contenta Corporation, Design Standards for Phase 1B Adopted by the City Planning Commission July 1997, 1998.8

9) Tierra Contenta Corporation, Design Standards for Phase 2A Adopted August 2000, 2003.3

10) Tierra Contenta Corporation, Design Standards for Phase 2B Adopted Adopted June 2003, 2003.10

11) Peter Calthorpe, The Next American Metropolis: Ecology, Community, and the American Dream, Princeton Architectural Press, 1993.6 (ピー ター・カルソープ著，倉田直道・倉田洋子訳，次世代のアメリカの都市づく ク一ニューアーバニズムの手法，学芸出版社，2004.6)

12）森傑, PFI 事業の提案書作成に扔けるエスノデザインメソッドの考察 Private Finance Initiativeの施設計画に関するエスノメソドロジー，日本 建築学会計画系論文集，第 595 号，pp.87-94，2005.9

13）NPO 法人里山俱楽部ホームページ : http://www.satoyama-club.org/ 